\title{
Effect of the Stakeholder Salience Theory on Family Businesses Performance
}

\author{
Paydaşların Önceliği Teorisinin Aile İşletmelerinin Performansına Etkisi \\ Mehmet Akif ÇiNi* \\ Hasan Kürşat GÜLEŞ*** \\ Mustafa Atilla ARICIOĞLU $\mathbf{U}^{* * * *}$
}

\begin{abstract}
Having started to develop since the second half of twentieth century, Family businesses make up approximately $\% 50$ in the world, \%90 in Turkey of all businesses. For that reason, presenting a good economic performance and ensuring sustainability of Family businesses plays a critical role for the whole world economies. Yet, the rate of taking-over the business from the founder of these businesses to the next generation gradually decreases. When the literature review, a lot of important reasons appears to be about this situation, like having more system compared to normal businesses. In the study, how the systems of Family businesses (family, business and management) effects the performance of the business through Stakeholders Salience Model (power, legitimacy and urgency) and which system will improve this performance best, is researched. Studying how the impact, salience and stakes of each system will affect economic performance of the business separately would fill that gap in the literature. In this research, in 12 provinces which consist of \%71 of Family businesses in Turkey (Istanbul, Ankara, Bursa, Izmir, Konya, Gaziantep, Denizli, Kocaeli, Adana, Tekirdağ, Kayseri and Mersin), data from 308 businesses that are large-sized in terms of the number of workers they employ, are analyzed with Structural Equation Model. In the study, two main and six sub hypothesis are analyzed and all of are accepted. Consequently, a positive relationship between salience and stake of each of main stakeholder group and business performance has been determined.
\end{abstract}

Key Words: Family Business, Stakeholder Theory, Business Performance

$\ddot{O} z$

Yirminci yüzyılın ikinci yarısından itibaren gelişmeye başlayan aile işletmeleri, tüm şirketlerinin Dünya'da ortalama \% 50'sini, Türkiye'de ise ortalama 95'ini oluşturmaktadır. Bu sebeple, aile işletmelerinin iyi bir ekonomik performans sergilemesi ve sürdürülebilirliğinin sağlanması tüm dünya ekonomileri için kritik bir rol oynamaktadır. Ancak, bu işletmelerin kurucusundan itibaren gelecek nesillere devredilme oranları gittikçe düşmektedir. Literatür incelendiğinde, aile işletmelerinin diğer işletmelere göre daha fazla sistem sahip olduğu gibi konuyla ilgili birçok neden olduğu görülmektedir. Çalışmada, aile işletmeleri sistemlerinin (aile, işletme ve yönetim), Paydaşların Önceliği Modeli (güç, meşruiyet ve öncelik) aracılığıyla işletmenin performansını nasıl etkilediği ve hangi sistemin bu performansı eniyileyeceği araştırılmıştır. Her bir sistemin etkisinin, önceliğinin ve çıkarlarının işletmenin ekonomik performansını nasıl etkilediğinin ayrı ayrı araştırılması, literatürdeki bu boşluğu dolduracaktır. Araştırma, Türkiye'de bulunan aile işletmelerinin \%71'ini kapsayan 12 ilde (İstanbul, Ankara, Bursa, İzmir, Konya, Gaziantep, Denizli, Kocaeli, Adana, Tekirdağ, Kayseri ve Mersin), çalıştırdığı işçi sayısı açısından büyük ölçekli 308 işletme üzerinde gerçekleştirilmiş ve elde edilen veriler, Yapısal Eşitlik Modeli aracılığıyla analiz edilmiştir.

Anahtar Kelimeler: Aile İşletmeleri, Paydaş Teorisi, İşletme Performansı

\section{Introduction}

Family businesses make up a huge part of the economy in the world. In this context, presenting successful economic performance and providing sustainability of Family businesses is important for all national economies. However, business performance of Family businesses from the point they are established and thereby decrease on the rate of succession to the next generation is an undeniable fact. When the literature is examined, it is seen that there are several factors that have effect on this decrease. In addition to this, Family businesses consist of many more stakeholder groups than normal businesses. So, this requires the determination of stakes

\footnotetext{
* Selçuk Üniversitesi Cihanbeyli Meslek Yüksekokulu Muhasebe ve Vergi Uygulamaları Bölümü, Edebiyat Fakültesi, Antropoloji Bölümü, mehmetakifcini@selcuk.edu.tr

** Konya Gıda Tarım Üniversitesi Sosyal ve Beşeri Bilimler Fakültesi Ekonomi Bölümü, kursat.gules@gidatarim.edu.tr

${ }_{* * *}^{*}$ Necmettin Erbakan Üniversitesi Sosyal ve Beşeri Bilimler Fakültesi İșletme Bölümü, maaricioglu@ @mail.com
}

Çini, M.A, Güleş, H.K, Arıcıoğlu, M.A, (2018). Effect of the Stakeholder Salience Theory on Family Businesses Performance, Gaziantep University Journal of Social Sciences, 17(4), 1491-1506, Submission Date: 31-05-2018, Acceptance Date: 27-09-2018.

Araştırma Makalesi. 
and developing various and different strategies against the conflicts that may occur. Especially, because all stakeholder groups have their own stakes, some approaches may remain superficial on the analysis of family businesses that involves many stakeholders.

\section{Family Owned-Businesses}

There is not any universal consensus on the subject of the meaning of family businesses concept. When the literature about the concept is examined, it is possible to find different definitions concentrating on different points. According to Mustakallio (2002, p.27), definitions in literature came under six titles. These are; ownership, management, passing between generations, family's aim to continue as family businesses, purposes of family and interaction between business and family.

In this context, Family businesses can be defined as businesses in which, a huge part of ownership and management positions belong to family members, aiming the economic sustenance of family of business for generations, a subsystem in system (stakeholder group) being more primary and effective compared to subsystems.

\section{Stakeholder Concept and Stakeholder Theory}

The concept of stakeholder was first used by E. Merrick Dodd in 1932. Dodd, as the result of his studies accompanied with the managers of General Electric Business, he stated that stakeholder groups are; shareholders, workers, customers and society. And in 1950s, CEO of Sears, Robert E. Wood categorized the stakeholder groups composed by Dodd according to order of importance in terms of businesses. This categorization was conducted as; customers, workers, society and shareholders (Preston and Sapienza, 1990, p.362). Concept was brought in to management literature in consequence of the studies conducted at Stanford Research Institute (SRI) in 1963 (Elias and Cavana, 2000, p.2) and were defined as "the groups, who would not be able to maintain their presence without the supports of businesses" (Mitchell et. al., 1997, p.858). Besides as a result of these studies, it is mentioned that managers, to reach business goals, which will be supported by stakeholders, have to understand well the requests and needs of shareholders, workers, customers, suppliers, banks and society. Because support of stakeholders to goals of businesses is accepted as the key to long-term success and sustainability and as a result, the relations of businesses and stakeholders are an important research field (Freeman and Mcvea, 2001, p.3).

When literature is reviewed, as some of the studies conducted on categorization of stakeholders handle them with a wide diversification as government, political groups, shareholders, financial institutions, activist (agitator) groups, consumers, groups defending consumer rights, unions, workers, trade associations, competitors and suppliers, some categorize it as classified customers, society, shareholders, government and workers. Most important studies were conducted by Freeman (1984), Lerner and Fryxell (1994), Morgan and Hunt (1994) and Droge and his colleagues (1990).

When categorization of stakeholders in terms of Family businesses is examined, it is seen that Family businesses differs from other businesses, especially in terms of internal stakeholders. The reason for this is the effect of family dynamics over the business. In terms of internal stakeholders, Family businesses show variety according to the roles that family member or non-family member people play. In Family businesses, as the roles played by family members are entrepreneur, successor and relatives, the roles played by non-family members are professional managers and partners (Kurt, 2009, p.68; Karpuzoğlu, 2000, p.23).

Stakeholder theory was suggested as an offer for strategic management of businesses by Freeman (1984) at the end of 20th century. In Freeman's study named "Strategic Management: A Stakeholder Approach", which is accepted as the beginning of the concept of stakeholder 
theory, how stakeholders have similar stakes and rights from the same group is explained, also the relation between business and its external environment, and behaviors of business within this environment is mentioned. Thorough the time, the theory provided a deep source thanks to the contributions of Clarkson (1994 and 1995), Donaldson and Preston (1995), Mitchell and colleagues (1997), Rowley (1997) and Frooman (1999) and gained more importance by progressing accordingly. From the first strategic perspective of the theory to now, various marketing based businesses adapted to run the theory as a management tool and developed it (Donaldson and Preston, 1995, p.65; Mainardes et. al., 2011, p.226; Rowley, 1997, p.887). Today the approach is used by many businesses with purpose of ensuring better financial success and locating what are the stakes of stakeholders to improve the relation of business with its community (Chevalier, 2001, p.1). Besides the theory, which was thought as a strategic management tool at first (Freeman, 1984), in the following years, also showed development as a theory about work ethics (Philips, 2003).

According to the theory, managers support all the processes and formulas, which satisfy all, benefit groups or all business actors. In other words, theory lets management to integrate solutions within the theory to the forecasts within strategic plan. The most important task in this process is integration of shareholders, workers, customers, suppliers, communities and other groups' stakes to each other and achieving long-term business success somehow. Besides the stakeholder theory emphasize the stakes, relations and business circle shared to be active on management (Freeman and Mcvea, 2001, p.10). Briefly, the theory identifies the expectations of stakeholders, experience and effects about the business, evaluation of observed results and activities of stakeholders about the business (Polonsky 1996, p.212; Post et. al. 2002, p.8; Neville, 2005, p.1187).

Stakeholder theory is developed to examine, analyze and realize the characteristic features of individuals or groups, who effect or are affected by the activities of the business. According to these the steps that theory should take (Clarkson, 1995, p.100, Donaldson and Preston, 1995, p.66; Rowley, 1997, p.887; Scott and Lane, 2000, p.44).

1) Identification of stakeholders

2) Explication of development process, stakes, needs and salience about stakeholders

3) Positioning of whole process' relational structure around the business's own stakes.

\section{Research Title}

\section{Purpose and Method of Research}

In this context, the main questions while forming the conceptual model of the research,

1) Who are the stakeholder groups, who are the real right owner within Family businesses?

2) What are the stakes and saliencies given to these groups?

3) How do these privileges affect the economic performance of the business?

In a business with these studies mentioned in literature, main stakeholder groups of Family businesses; it is specified as family members representing the family, shareholders representing the property and business managers representing management.

After determination of main stakeholder groups, (the second question) "privileges given to main stakeholder groups" is tried to be specified. The most general accepted study in literature to these privileges is "Stakeholder Salience" model conducted by Mitchell et. al. (1997). 
According to Stakeholder Salience Theory, power, legitimacy and urgency are the criteria that stakeholders want to have. Power is can affect or is affected by the achievement of the organization's objectives (Freeman, 1984, p.46). Urgency is as the degree to which stakeholder claims call for immediate attention and legitimacy is desirable social good, that it is something larger and more shared than a mere self-perception, and that it may be defined and negotiated differently at various levels of social organization (Mitchell et. al., 1997, s. 867). The degree of having these criteria increases or decreases stakes and saliencies of stakeholder within the business. In other words, For Agle et al. (1999), Stakeholder Salience Theory is defined as "the degree to which managers give priority to competing stakeholder claims". Thus, stakeholder salience is positively related to the cumulative number of the stakeholder attributes present. For example, when a stakeholder possesses all three of the attributes, a manager is more likely to give high priority to meeting that stakeholder's demands when making decisions. As the number of attributes decrease, the priority of the claims also decreases (Ring, 2011, p.31). In this study, concept of "Stakes" is used instead of Power and concept of "Saliencies" is used instead of Urgency. Legitimacy states the validity of any stakeholder within the business and privileges related to this. The privilege of legitimacy is not used as a criterion in this research, because participants in this research can be chosen in legitimate family members.

The third question of our study, to scale the effect of stakes and saliencies belonging to stakeholders, to the business's performance sustainability, the methods, which were used by Mitchell et. al. (1997, p.8), Ring (2011, p.58) and Erdirençelebi (2013) is used. As Erdirençelebi was developing this scale, he benefited from the scale used by Chua et. al. (1999), Ateş (2001), Sonfield and Lussier (2004), Özuysal (2006), İçin (2008) and Mustakallio (2002).

In this context, the main purpose of this study; is to reveal whether or not the saliencies and stakes of (based upon stakeholder salience model) main stakeholder groups within Family businesses (family members, stakeholders and managers) has effect on economic performance of the business (qualitative or quantitative).

\section{Research Sample}

As the extent and size of the sample of the study is determined, "81 Province Industry Report" data issued in December 2013 by Ministry of Science, Industry and Technology is used. As the sample extent of the study is specified, 12 provinces out of 81 provinces were chosen (İstanbul, Bursa, Ankara, İzmir, Konya, Gaziantep, Denizli, Kocaeli, Adana, Tekirdağ, Kayseri, and Mersin). The reason why these 12 regions were chosen is that total business number in these provinces forms $\% 71$ of businesses in our country. When the purpose and hypothesis of the study is taken notice, the opinion of necessity to conduct that research on businesses, which has high level of institutionalism and in this context including large-sized businesses to the study was seen appropriate. Thereby, the size of the study was determined as 1.074 large-sized businesses located in 12 provinces. Among these businesses, the criteria required for determining businesses relevant to the purpose of the study;

a) Having at least 251 workers, one of the criteria of business size scale,

b) Having at least two people, who has kindred ship or same surname at senior management board of business, to be surveyed,

c) Family members in business management should have at least total \%51 share.

The "a" article on the list was prepared for businesses' size scale; "b" and "c" article was prepared for businesses to be evaluated as Family businesses. While the list was prepared, for article "a", data from Provincial Directorate of Industry and Provincial Chambers of Commerce and "2013, 500 Large Industrial Enterprise of Turkey" issued by Istanbul Industry Chamber was used. For article "b" and "c", "Information Services" in business's website and 
information in various websites was used. During the preparation of the list, for Istanbul province mentioned and 465 business matching with article "a" fell short when evaluated by article "b" and "c". In other words, it is located that most of that 465 large-sized businesses operating in Istanbul lost their feature of being a family businesses. In this context, only in this province, medium-sized businesses were also included to extent of the study. As a result, 510 large and medium-sized Family businesses, which are operating in 12 provinces and fit to all criteria, were included. Therefore, the extent of the study was revised as 510 businesses. According to that located extent, the size of the sample was calculated as 289 at \%99 meaningfulness level according to $\% 5$ acceptable error ratio. When inappropriate surveys are eliminated, it is seen that only 308 of 510 businesses was contacted. This equals to \%56, 6 of participation rate.

In the study survey method, which is a primal data gathering method, was preferred and for the surveys to be completed a business being expert on data gathering was hired and business collected all data according to face-to-face meeting principal. Survey form was prepared according to Likert's five point scale (1=Strongly Disagree, 5=Strongly Agree). Survey questions consist of scales and questions taken exactly or extensionally (reliability and validity proved) from present literature studies. In this context, the survey questions consist of; aimed at scaling the quantitative and qualitative economic performance of family businesses, 8 propositions used by Ring (2011) and Erdirençelebi (2013), aimed at scaling sustainability of Family businesses, 13 propositions composed of 3 major topics (independent board of directors, Succession Plan and labor management) used by Erdirençelebi (2011), and aimed at scaling salience and stakes of family businesses stakeholders, $27(12+15)$ propositions composed of 3 major topics (family members, shareholder and managers) used by Ring (2011) (1= Strongly Disagree, 5=Strongly Agree).

\section{Research Findings}

Family businesses, participated in research, operating in 20 different sector, and the most participation of first three sectors are in order, \%35, 06 (106) Textile, \%12, 66 (39) Food and \%6, 49 (20) Machine and Equipment Industries. The least participation came from Consultancy and Tourism with \% 0, 65(2) rate.

When the participant businesses are examined by province, the most participation consist of businesses operating, in order, in Istanbul \%49, 03 (151), Bursa \%9, 09 (28) and Kocaeli \% 7, 47 (23), and the least participation came from Mersin \%0, 97 (3).

According to their legal structure, \%93, 18 (287) of them are Incorporated Business, \%6, 82 (21) of them are Limited Business. Average operation period of the businesses participated in the research is 30 years.

According to their operation period, the most participation came from "31-50 years" with \%45, 45 (140) and the least from " $1-10$ years" with \% 3, 57(11).

According to size scale, \% 88 (272) of participant businesses, as to number of workers, to 251 and more workers and as to annual turnover, having 40 Million TL and over revenue, are large-sized businesses. And \%12 of them is medium-sized businesses with 151-250 workers and 8-39 Million TL annual revenue. Furthermore, according to "Turkey's First and Second 500 Large Industry Enterprises" report dated 2013 of Istanbul Chamber of Industry, \% 23,05 (71) of businesses participated to the research are in "Turkey's First 500 Large Industry Enterprises", \% 22,73 (70) of businesses are in "Turkey's Second 500 Large Industry Enterprises".

When the stock share rate of businesses participated in research, \%82 (252) of them are among "\% $\% 6-100 "$ and \%18 (56) of them are among "\%51-75". 


\section{Research Hypotheses}

H1: Saliencies of stakeholder groups within Family businesses have positive effect on economic performance of the business.

Hla: There is a positive relationship between saliencies of stakeholders within family businesses and business performance.

H1b: There is a positive relationship between saliencies of family members within family businesses and business performance

Hlc: There is a positive relationship between saliencies of managers within family businesses and business performance.

H2: Stakes of stakeholder groups within Family businesses have positive effect on economic performance of the business.

H2a: There is a positive relationship between stakes of stakeholders within family businesses and business performance.

$H 2 b$ : There is a positive relationship between stakes of family members within family businesses and business performance.

H2c: There is a positive relationship between stakes of managers within family businesses and business performance

\section{Research Analysis}

In the research, firstly reliability analysis and Exploratory Factor Analysis methods are used. Later on, Confirmatory Factor analysis was used to verify Exploratory Factor Analysis, Correlation analysis was used to test sub-hypothesis, Structural Equation Analysis was used to test main hypothesis and to establish model.

\section{Reliability and exploratory factor analysis}

In exploratory factor analysis, in order to find most appropriate analysis, the criteria of factors having over 1 eigenvalue and the criteria of factor loads being over 0,50 rates are stipulated. Additionally, it was taken notice that in the case that eigenvalue is over 1 , in the case of factor amount being unable to explain $2 / 3$ of total variance, $2 / 3$ of total variance amount of stated variance ratio to be factor amount. As analysis was made, factor amount that each variable is connected was expected to be high, factors, which were below 0,50 was excluded from the analysis. In addition to this, each variable were expected to have high load value at one factor and low load value at other factor and variables that have below 0,40 rate difference between both values were excluded from scale. Exploratory Factor Analysis results about all scales are shown at Table 1.

Table 1: The exploratory factor analysis of the surveying model

\begin{tabular}{|c|c|c|c|c|c|}
\hline \multicolumn{6}{|c|}{ The Business Performance } \\
\hline Size & Material & Factor Load & Variance & Cronbach's Alpha & Eigenvalue \\
\hline \multirow{4}{*}{ Qualitative } & q9 & 0,71 & \multirow{4}{*}{43,35} & \multirow{4}{*}{0,848} & \multirow{4}{*}{3,08} \\
\hline & q10 & 0,91 & & & \\
\hline & q11 & 0,81 & & & \\
\hline & q12 & 0,65 & & & \\
\hline \multirow{3}{*}{ Quantitative } & q13 & 0,75 & \multirow{3}{*}{27,55} & \multirow{3}{*}{0,785} & \multirow{3}{*}{2,2} \\
\hline & q14 & 0,8 & & & \\
\hline & $q 15$ & 0,68 & & & \\
\hline
\end{tabular}




\begin{tabular}{|c|c|c|c|c|c|}
\hline \multicolumn{6}{|c|}{ Stakeholder Salience } \\
\hline Size & Material & Factor Load & Variance & Cronbach's Alpha & Eigenvalue \\
\hline \multirow{3}{*}{ Stakeholder Salience } & $\mathrm{q} 30$ & 0,69 & \multirow{3}{*}{29,02} & \multirow{3}{*}{0,78} & \multirow{3}{*}{2,14} \\
\hline & q32 & 0,70 & & & \\
\hline & $\mathrm{q} 33$ & 0,75 & & & \\
\hline \multirow{3}{*}{ Family Salience } & q34 & 0,74 & \multirow{3}{*}{30,15} & \multirow{3}{*}{0,8} & \multirow{3}{*}{2,29} \\
\hline & q36 & 0,88 & & & \\
\hline & $\mathrm{q} 37$ & 0,67 & & & \\
\hline \multirow{2}{*}{ Manager Salience } & q38 & 0,59 & \multirow{2}{*}{20,4} & \multirow{2}{*}{0,7} & \multirow{2}{*}{1,2} \\
\hline & $\mathrm{q} 41$ & 0,61 & & & \\
\hline
\end{tabular}

$\mathrm{n}=8 ; \mathrm{KMO}=0,87 ;$ Barlett Sph. Chi-Square $=1023,251 ;$ Total Variance $=\% 79,57 ;$ Cronbach's Alpha: 0,87;

Factor Loadings $\geq 0,50$.

\begin{tabular}{|c|c|c|c|c|c|}
\hline \multicolumn{6}{|c|}{ Stakeholder Stake } \\
\hline Size & Material & Factor Load & Variance & Cronbach's Alpha & Eigenvalue \\
\hline \multirow{4}{*}{ Stakeholder Stake } & $\mathrm{q} 42$ & 0,87 & \multirow{4}{*}{27,13} & \multirow{4}{*}{0,93} & \multirow{4}{*}{4,22} \\
\hline & $\mathrm{q} 43$ & 0,90 & & & \\
\hline & $\mathrm{q} 44$ & 0,84 & & & \\
\hline & $\mathrm{q} 45$ & 0,86 & & & \\
\hline \multirow{4}{*}{ Family Stake } & $\mathrm{q} 47$ & 0,8 & \multirow{4}{*}{28,45} & \multirow{4}{*}{0,89} & \multirow{4}{*}{3,28} \\
\hline & $\mathrm{q} 48$ & 0,77 & & & \\
\hline & q50 & 0,89 & & & \\
\hline & q51 & 0,82 & & & \\
\hline \multirow{3}{*}{ Manager Stake } & q52 & 0,73 & \multirow{3}{*}{24,64} & \multirow{3}{*}{0,85} & \multirow{3}{*}{2,42} \\
\hline & q53 & 0,84 & & & \\
\hline & $\mathrm{q} 54$ & 0,85 & & & \\
\hline
\end{tabular}

$\mathrm{n}=12 ; \mathrm{KMO}=0,92 ;$ Barlett Sph. Chi-Square $=3075,998 ;$ Total Variance $=\% 90,22 ;$ Cronbach's Alpha: 0,94;

Factor Loadings $\geq 0,50$.

In order to make factor analysis of the scales, KMO, Barlett and reliability values is required to go up over critical points. In this context for every scale, factor analysis was made and to increase independence and expressiveness level in analysis, values, whose factor loads remain below 0,50, was eliminated using varimax axis rotation technique. Furthermore, it was confirmed that eigenvalue of all scales are over 1.

The general reliability of "Business Performance" scale was discovered to be 0,87 , in results of KMO and Barlett analysis, it was confirmed that KMO value is 0,86 and Barlett value is below 0,05, and it is seen that execution of factor analysis is possible. One article, which did not provide the scale (Article 16), was excluded from the scale. As a result of factor analysis, two factors which with \% 70,90 total variance occurred. "Saliencies of Stakeholders", as mentioned in the main purpose of the research, was formed by organizing separate factors for each of main stakeholder groups within Family businesses. In this context, factors, which became the content of the research, was specified as "Saliencies of Stakeholders", "Saliencies of Family Members" and "Saliencies of Managers". When examined "Saliencies of Stakeholders" scale, it is seen that factors provide required conditions to be able to make factor analysis of scale. In other words, $\operatorname{KMO}(0,87)$, Barlett $(\mathrm{p}<0,05)$ and general reliability $(0,87)$ 
values are over the desired values to continue analyzing. Four articles staying below critical value at stakeholder salience scale (Article 31, 35, 39, 40) was excluded from scale and was not subjected to evaluation. As a result of factor analysis, total variance of each three scale was calculated as \% 79, 57. The process of forming "Stakes of Stakeholders" scale includes similarities with the process of forming "Saliencies of Stakeholders". In this context, it is seen that $\operatorname{KMO}(0,92)$, Barlett $(\mathrm{p}<0,005)$ and general reliability $(0,94)$ values are at required level to make factor analysis. In this scale, varimax rotation technique is used and (the ones, whose factor loads remained under 0, 50) four articles (Article 46, 49, 55 and 56) was excluded from the scale. As a result of factor analysis executed, total variance rate of each three factor is $\% 80$, 22 .

\section{Confirmatory factor analysis}

In this part of the research, primarily for literature evaluation and to confirm the correctness of factors obtained with exploratory factor analysis, first and second level confirmatory factor analysis was executed. In this context, factor structures were transferred to AMOS 16 package program. Afterwards via program, it was stated that modification index is required for some factors, whose fault variances are over 1,00 and standard regression weights value is below0,50, and it is confirmed that they have to be excluded from the scale. However, the values were reviewed later on and it was realized that they are important for the model and could be valid as conceptual. First level confirmatory factor analysis findings about observed flexible of factors forming "Business Performance", "Stakeholders Salience" and "Stakeholders Stake" scales in Table 2, is shown.

Table 2: The first level confirmatory factor analysis of the surveying model

\begin{tabular}{|c|c|c|c|c|c|c|c|}
\hline \multirow{10}{*}{ 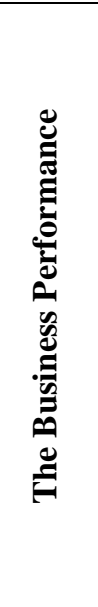 } & Sub factor & $\begin{array}{l}\text { Material } \\
\text { No }\end{array}$ & $\begin{array}{c}\text { Standard Regression } \\
\text { Gap Values }\end{array}$ & $t$ & $\mathbf{P}$ & Variance & C.Alpha \\
\hline & \multirow{4}{*}{ Qualitative } & q9 & 0,71 & - & $<0,001$ & \multirow{4}{*}{43,35} & \multirow{4}{*}{0,848} \\
\hline & & q10 & 0,91 & 13,07 & $<0,001$ & & \\
\hline & & q11 & 0,81 & 11,03 & $<0,001$ & & \\
\hline & & $\mathrm{q} 12$ & 0,65 & 10,46 & $<0,001$ & & \\
\hline & \multirow{5}{*}{ Quantitative } & q13 & 0,75 & - & $<0,001$ & \multirow{5}{*}{27,55} & \multirow{5}{*}{0,785} \\
\hline & & q14 & 0,80 & 8,7 & $<0,001$ & & \\
\hline & & $q 15$ & 0,68 & 7,9 & $<0,001$ & & \\
\hline & & $\mathrm{q} 23$ & 0,65 & 12,33 & $<0,001$ & & \\
\hline & & $\mathrm{q} 24$ & 0,68 & 13,1 & $<0,001$ & & \\
\hline \multirow{8}{*}{  } & \multirow{3}{*}{$\begin{array}{l}\text { Stakeholder } \\
\text { Salience }\end{array}$} & q30 & 0,69 & - & $<0,001$ & \multirow{3}{*}{29,02} & \multirow{3}{*}{0,78} \\
\hline & & q32 & 0,70 & 9,67 & $<0,001$ & & \\
\hline & & q33 & 0,75 & 8,59 & $<0,001$ & & \\
\hline & \multirow{3}{*}{ Family Salience } & q34 & 0,74 & - & $<0,001$ & \multirow{3}{*}{30,15} & \multirow{3}{*}{0,80} \\
\hline & & q36 & 0,88 & 13,84 & $<0,001$ & & \\
\hline & & q37 & 0,67 & 11,85 & $<0,001$ & & \\
\hline & \multirow{2}{*}{$\begin{array}{l}\text { Manager } \\
\text { Salience }\end{array}$} & q38 & 0,59 & - & $<0,001$ & \multirow{2}{*}{20,40} & \multirow{2}{*}{0,70} \\
\hline & & $\mathrm{q} 41$ & 0,61 & 8,75 & $<0,001$ & & \\
\hline \multirow{4}{*}{ 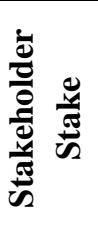 } & \multirow{4}{*}{$\begin{array}{l}\text { Stakeholder } \\
\text { Stake }\end{array}$} & $q 42$ & 0,88 & - & $<0,001$ & \multirow{4}{*}{27,13} & \multirow{4}{*}{0,93} \\
\hline & & q43 & 0,91 & 23,14 & $<0,001$ & & \\
\hline & & $\mathrm{q} 44$ & 0,85 & 20,03 & $<0,001$ & & \\
\hline & & $\mathrm{q} 45$ & 0,83 & 19,14 & $<0,001$ & & \\
\hline
\end{tabular}




\begin{tabular}{|c|c|c|c|c|c|c|}
\hline \multirow{4}{*}{ Family Stake } & $\mathrm{q} 47$ & 0,82 & - & $<0,001$ & \multirow{4}{*}{28,45} & \multirow{4}{*}{0,89} \\
\hline & $\mathrm{q} 48$ & 0,79 & 15,65 & $<0,001$ & & \\
\hline & q50 & 0,82 & 16,51 & $<0,001$ & & \\
\hline & q51 & 0,61 & 11,1 & $<0,001$ & & \\
\hline \multirow{3}{*}{ Manager Stake } & q52 & 0,87 & - & $<0,001$ & \multirow{3}{*}{24,64} & \multirow{3}{*}{0,85} \\
\hline & q53 & 0,83 & 18,31 & $<0,001$ & & \\
\hline & q54 & 0,78 & 16,2 & $<0,001$ & & \\
\hline
\end{tabular}

After each scale's connection with sub-flexible was observed via first level confirmatory factor analysis, second level confirmatory factor analysis, which observes all scales together, was used. At this stage, the value of 0,50 were considered as standard forecast value lower limit. Second level confirmatory factor analysis results about model are in Table 3. Standard load value belonging to each scale was given and value of 0,50 was considered as lower limit. As a result, it was founded that all scales are over the value of 0,50 and thus all scales are compatible and meaningful as statistically.

Table 3: The second level confirmatory factor analysis of the surveying model

\begin{tabular}{|c|c|c|c|}
\hline & Sub factor & $\begin{array}{c}\text { Standard Regression } \\
\text { Gap Values }\end{array}$ & $\mathbf{P}$ \\
\hline \multirow{2}{*}{ 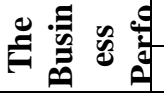 } & Qualitative Performance & 0,83 & $<0,001$ \\
\hline & Quantitative Performance & 0,85 & $<0,001$ \\
\hline \multirow{3}{*}{ 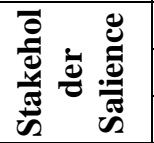 } & Stakeholder Salience & 0,82 & $<0,001$ \\
\hline & Family Salience & 0,92 & $<0,001$ \\
\hline & Manager Salience & 0,94 & $<0,001$ \\
\hline \multirow{3}{*}{ 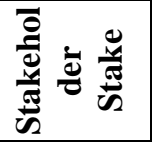 } & Stakeholder Stake & 0,7 & $<0,001$ \\
\hline & Family Stake & 0,98 & $<0,001$ \\
\hline & Manager Stake & 1,03 & $<0,001$ \\
\hline
\end{tabular}

In Table 4, standard forecast values (factor loads), $t$ values, reliability values and standard error value of all flexible in scale model is shown. At this stage, variance lowest limit needs to be 0,50 and structure reliability needs to be 0,70 . As a result, since the model goodness of fit value was in use, later, structural part, which is the second stage of the structural equation model, was used.

Table 4: The extents taking place in the surveying model

\begin{tabular}{|c|c|c|c|c|c|c|c|c|}
\hline \multirow{10}{*}{\multicolumn{2}{|c|}{ 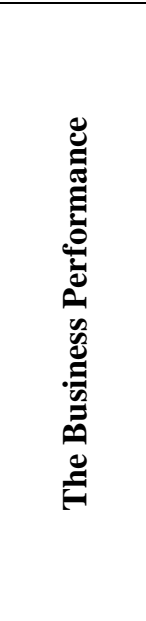 }} & Sub factor & $\begin{array}{c}\text { Material } \\
\text { No }\end{array}$ & $\begin{array}{c}\text { The } \\
\text { Standard } \\
\text { Estimates }\end{array}$ & $\begin{array}{c}\text { The } \\
\text { Standard } \\
\text { Faults }\end{array}$ & $t$ & V.E. & $\mathbf{A}$ \\
\hline & & \multirow{4}{*}{ Qualitative } & q9 & 0,88 & - & - & \multirow{4}{*}{59} & \multirow{4}{*}{0,85} \\
\hline & & & q10 & 0,82 & 0,052 & 17,301 & & \\
\hline & & & q11 & 0,66 & 0,048 & 12,459 & & \\
\hline & & & q12 & 0,78 & 0,059 & 14,742 & & \\
\hline & & \multirow{5}{*}{ Quantitative } & q13 & 0,7 & - & - & \multirow{5}{*}{55} & \multirow{5}{*}{0,79} \\
\hline & & & q14 & 0,74 & 0,105 & 11,182 & & \\
\hline & & & q15 & 0,78 & 0,104 & 10,524 & & \\
\hline & & & q23 & 0,74 & 0,107 & 11,084 & & \\
\hline & & & q24 & 0,83 & 0,113 & 12,09 & & \\
\hline \multirow{3}{*}{$\begin{array}{l}\frac{0}{0} \\
\frac{2}{0} \\
\frac{4}{\pi} \\
\frac{\pi}{0}\end{array}$} & \multirow{3}{*}{ ¿ } & \multirow{3}{*}{ Stakeholder Salience } & q30 & 0,78 & - & - & \multirow{3}{*}{58} & \multirow{3}{*}{0,8} \\
\hline & & & q32 & 0,71 & 0,073 & 12,688 & & \\
\hline & & & q33 & 0,8 & 0,084 & 11,149 & & \\
\hline
\end{tabular}




\begin{tabular}{|c|c|c|c|c|c|c|c|}
\hline & \multirow{3}{*}{ Family Salience } & $\mathrm{q} 34$ & 0,74 & - & - & \multirow{3}{*}{61} & \multirow{3}{*}{0,76} \\
\hline & & q36 & 0,82 & 0,106 & 10,948 & & \\
\hline & & q37 & 0,85 & 0,105 & 10,851 & & \\
\hline & \multirow{2}{*}{ Manager Salience } & q38 & 0,73 & - & - & \multirow{2}{*}{80} & \multirow{2}{*}{0,7} \\
\hline & & $\mathrm{q} 41$ & 0,75 & 0,12 & 10,256 & & \\
\hline \multirow{11}{*}{ 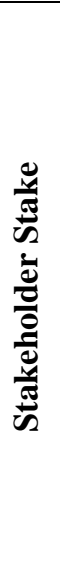 } & \multirow{4}{*}{ Stakeholder Stake } & $\mathrm{q} 42$ & 0,88 & - & - & \multirow{4}{*}{75} & \multirow{4}{*}{0,92} \\
\hline & & $\mathrm{q} 43$ & 0,91 & 0,045 & 23,187 & & \\
\hline & & $\mathrm{q} 44$ & 0,85 & 0,047 & 20,083 & & \\
\hline & & $\mathrm{q} 45$ & 0,84 & 0,048 & 19,341 & & \\
\hline & \multirow{4}{*}{ Family Stake } & $\mathrm{q} 47$ & 0,74 & - & - & \multirow{4}{*}{66} & \multirow{4}{*}{0,88} \\
\hline & & $\mathrm{q} 48$ & 0,82 & 0,09 & 14,325 & & \\
\hline & & q50 & 0,85 & 0,086 & 15,074 & & \\
\hline & & q51 & 0,82 & 0,08 & 14,5 & & \\
\hline & \multirow{3}{*}{ Manager Stake } & q52 & 0,79 & - & - & \multirow{3}{*}{80} & \multirow{3}{*}{0,76} \\
\hline & & q53 & 0,78 & 0,068 & 14,933 & & \\
\hline & & q54 & 0,77 & 0,076 & 17,252 & & \\
\hline
\end{tabular}

In Table 5, fit indices of all scales within the research are shown. Apart from GFI and AGFI fit indices, model fit indices are at good and excellent level. As subject indices were at acceptable level, the analysis was continued. Thus, Sharma (2005) criticized that GFI and AGFI fit indices are so sensitive against sample number and model disordinance and stated that these indices lost their importance (as cited in Hooper et. al, 2008, p.54).

Table 5: The goodness of fit results of the surveying model

\begin{tabular}{|c|c|c|c|c|}
\hline Compliance Index & Criteria & $\begin{array}{c}\text { Breakpoints to } \\
\text { Accept }\end{array}$ & $\begin{array}{c}\text { Goodness of } \\
\text { Fit Results }\end{array}$ & The Result \\
\hline$x^{2} / \mathbf{d f}$ & & $\leq 2=$ perfect fit & $\begin{array}{r}1,99 \\
\mathrm{df}=411\end{array}$ & Perfect fit \\
\hline GFI & $\begin{array}{l}0 \text { (does not fit) } \\
1 \text { (perfect fit) }\end{array}$ & $\begin{array}{l}\geq 0,85=\text { Acceptable } \\
\text { compliance } \\
\geq 0,90=\text { good fit } \\
\geq 0,95=\text { perfect fit }\end{array}$ & 0,85 & $\begin{array}{l}\text { Acceptable } \\
\text { compliance }\end{array}$ \\
\hline AGFI & $\begin{array}{l}0 \text { (does not fit) } \\
1 \text { (perfect fit) }\end{array}$ & $\begin{array}{l}\geq 0,80=\text { Acceptable } \\
\text { compliance } \\
\geq 0,90=\text { good fit } \\
\geq 0,95=\text { perfect fit }\end{array}$ & 0,82 & $\begin{array}{l}\text { Acceptable } \\
\text { compliance }\end{array}$ \\
\hline CFI & $\begin{array}{c}0 \text { (does not fit) } \\
1 \text { (perfect fit) }\end{array}$ & $\begin{array}{l}\geq 0,90=\text { good fit } \\
\geq 0,95=\text { perfect fit }\end{array}$ & 0,93 & Good fit \\
\hline RMSEA & $\begin{array}{l}0 \text { (does not fit) } \\
1 \text { (perfect fit) }\end{array}$ & $\begin{array}{l}\leq 0.05=\text { perfect fit } \\
\leq 0,06=\text { good fit } \\
\leq 0,07=\text { good fit } \\
\leq 0,08=\text { good fit } \\
\leq 0,10=\text { poor } \\
\text { compliance }\end{array}$ & 0,05 & Perfect fit \\
\hline NNFI & $\begin{array}{l}0 \text { (does not fit) } \\
1 \text { (perfect fit) }\end{array}$ & $\begin{array}{l}\geq 0,90=\text { good fit } \\
\geq 0,95=\text { perfect fit }\end{array}$ & 0,92 & Good fit \\
\hline
\end{tabular}

\section{Correlation analysis}

In the research, Pearson Correlation Analysis was used to examine the connection of benefit and saliencies of each stakeholder group to economic performance of the business, and analysis results done with one-tailed test was shown according to each scale. Additionally, subhypothesis of the study was tested through related tables. 
Correlation analysis results of the relationship between saliencies and stakes of main stakeholder groups within Family businesses (stakeholders, family members and managers) and business performance, was showed in order at Table 7.

Table 7: The correlation analysis results for stakeholder salience and stake

\begin{tabular}{|c|c|c|c|c|c|}
\hline \multicolumn{2}{|c|}{ STAKEHOLDER SALIENCE } & $\begin{array}{c}\text { Stakeholder } \\
\text { Salience }\end{array}$ & $\begin{array}{c}\text { Family } \\
\text { Salience }\end{array}$ & $\begin{array}{c}\text { Manager } \\
\text { Salience }\end{array}$ & $\begin{array}{l}\text { THE BUSINESS } \\
\text { PERFORMANCE }\end{array}$ \\
\hline \multirow{2}{*}{ Stakeholder Salience } & $r$ & 1 & 0,695 & 0,586 & 0,46 \\
\hline & $p$ & - & $<0,001$ & $<0,001$ & $<0,001$ \\
\hline \multirow{2}{*}{ Family Salience } & $r$ & 0,695 & 1 & 0,512 & 0,503 \\
\hline & $p$ & $<0,001$ & - & $<0,001$ & $<0,001$ \\
\hline \multirow{2}{*}{ Manager Salience } & $r$ & 0,586 & 0,512 & 1 & 0,493 \\
\hline & $p$ & $<0,001$ & $<0,001$ & - & $<0,001$ \\
\hline \multirow{2}{*}{ THE BUSINESS PERFORMANCE } & $r$ & 0,46 & 0,503 & 0,493 & 1 \\
\hline & $p$ & $<0,001$ & $<0,001$ & $<0,001$ & - \\
\hline \multicolumn{2}{|l|}{ STAKEHOLDER STAKE } & $\begin{array}{l}\text { Stakeholder } \\
\text { Stake }\end{array}$ & $\begin{array}{c}\text { Family } \\
\text { Stake }\end{array}$ & $\begin{array}{l}\text { Manager } \\
\text { Stake }\end{array}$ & $\begin{array}{l}\text { THE BUSINESS } \\
\text { PERFORMANCE }\end{array}$ \\
\hline \multirow{2}{*}{ Stakeholder Stake } & $r$ & 1 & 0,59 & 0,267 & 0,415 \\
\hline & $p$ & - & $<0,001$ & $<0,001$ & $<0,001$ \\
\hline \multirow{2}{*}{ Family Stake } & $r$ & 0,59 & 1 & 0,378 & 0,482 \\
\hline & $p$ & $<0,001$ & - & $<0,001$ & $<0,001$ \\
\hline \multirow{2}{*}{ Manager Stake } & $r$ & 0,267 & 0,378 & 1 & 0,265 \\
\hline & $p$ & $<0,001$ & $<0,001$ & - & $<0,001$ \\
\hline \multirow{2}{*}{ THE BUSINESS PERFORMANCE } & $r$ & 0,415 & 0,482 & 0,265 & 1 \\
\hline & $p$ & $<0,001$ & $<0,001$ & $<0,001$ & - \\
\hline
\end{tabular}

As seen on values given at Table 7 , it is found that there is a positive relationship between "Saliencies of Stakeholders $(r=0,46$; $p<0,001)$, Family members $(r=0,503 ; p<$ $0,001)$ and Managers $(r=0,493 ; p<0,001)$ " with "Performance of the Business" and these results support $\mathrm{H} 1 \mathrm{a}, \mathrm{H} 1 \mathrm{~b}, \mathrm{H} 1 \mathrm{c}$ hypothesis. As a result, it can be said that there is a mathematically positive and meaningful relationship between saliencies belonging to main stakeholder groups (stakeholders, family members and managers) with performance of the business.

When the relationship between "Stake of Stakeholders" (stakeholders, $r=0,415 ; p<$ $0,001$; family members, $r=0,482 ; p<0,001$; managers, $r=0,265 ; p<0,001)$, "Performance of the Business" scales is examined, that there is a mathematically meaningful and positive relationship again is shown at Table 7. Therefore, $\mathrm{H} 2 \mathrm{a}, \mathrm{H} 2 \mathrm{~b}, \mathrm{H} 2 \mathrm{c}$, hypothesis are confirmed. Consequently, when the research findings are evaluated, it can be stated that there is a positive relationship between stakes of stakeholders, family members and managers with performance of the business.

\section{Structural equation analysis}

Main purpose in the research model is to find the relationship between potential flexible (scales).For this reason $t$ values were reviewed at $\% 5$ meaningfulness. Path analysis obtained as a result of analysis done was shown at Figure 1, evaluation of hypothesis related with model was shown at Table 8 .

Table 8: The hypotheses results in the context of research model

\begin{tabular}{|l|c|l|l|l|c|}
\hline Hypotheses & The Estimation & SH & $\boldsymbol{T}$ & $\mathbf{p}$ & Result \\
\hline $\begin{array}{l}\text { H1: Saliencies of stakeholder groups within } \\
\text { Family businesses have positive effect on } \\
\text { economic performance of the business. }\end{array}$ & 0,54 & 0,116 & 4,67 & $<0,001$ & Approved \\
\hline $\begin{array}{l}\text { H2: Stakes of stakeholder groups within } \\
\text { Family businesses have positive effect on } \\
\text { economic performance of the business. }\end{array}$ & 0,17 & 0,046 & 3,48 & $<0,001$ & Approved \\
\hline
\end{tabular}




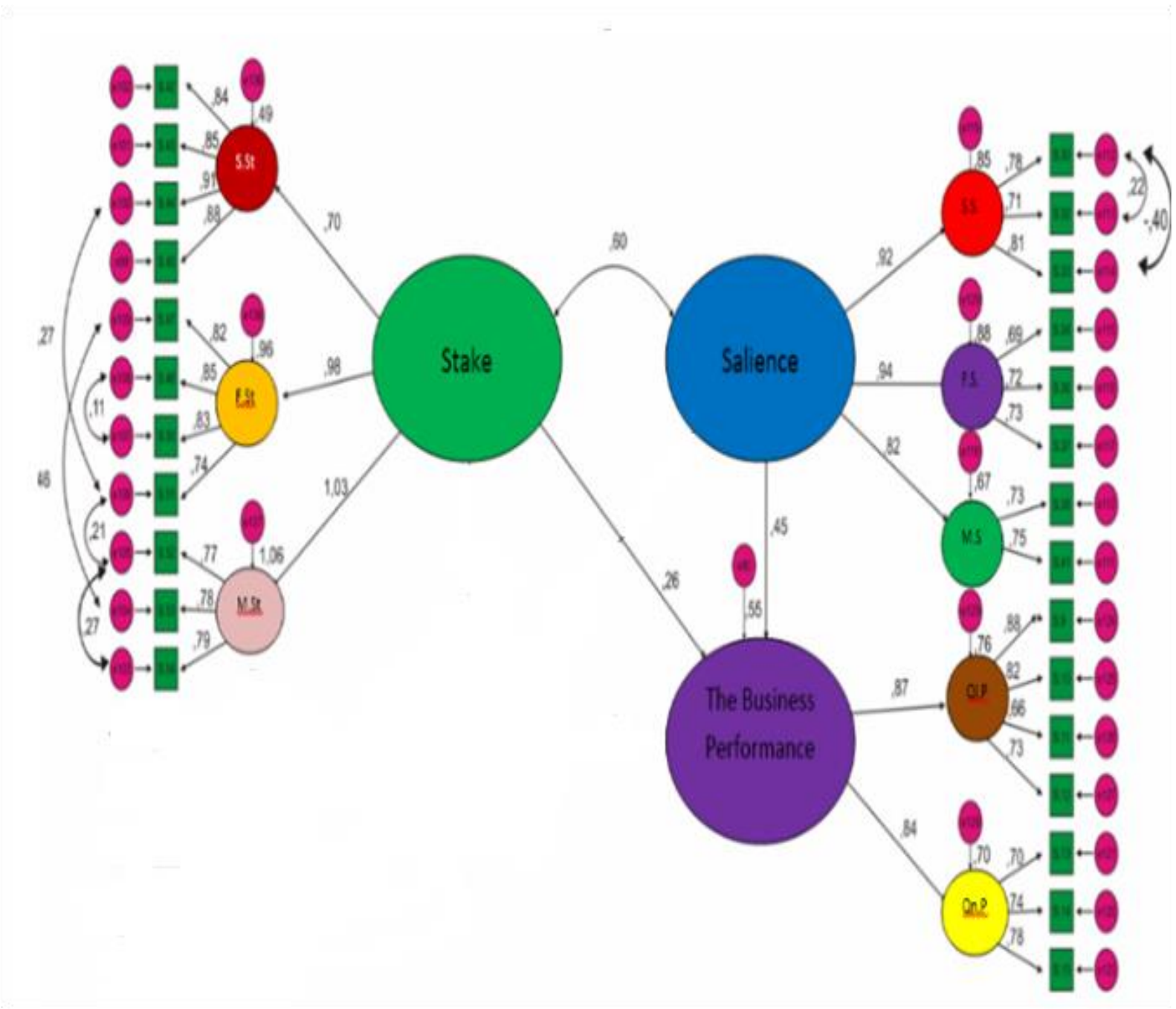

Figure 1: Results of structural equation analysis on the research conceptual model The following abbreviations are used in Figure 1.

S.St: Stakeholder Stake, F.St.: Family Stake, M.St.: Manager Stake, I.M.B.: Independent (Management) Board, p.P.: Sucession Plan. p.S.: Stakeholder Salience, F.S.: Family Salience, M.S.: Manager Salience, Q1.P.: Qualitative Performance, Qn.P.: Quantitative Performance.

As can be seen at Table 8, Hypothesis 1 as "Saliencies of stakeholder groups within the family-owned companies have positive effect on economic performance of the business" is accepted. As mentioned before (Table 7), H1a (there is a positive relationship between the saliencies of stakeholders and economic performance of the business) was confirmed as subhypothesis of $\mathrm{H} 1 \mathrm{~b}$ (there is a positive relationship between the saliencies of family members and economic performance of the business), and H1c (there is a positive relationship between saliencies of managers and economic performance of the business).

In addition to this, "Stakes of stakeholder groups within Family businesses have positive effect on economic performance of the business" was confirmed at Hypothesis 2 as a result of SEM analysis (Table 8). Besides correlation analysis results executed (Table 7), also supports sub-hypothesis formed as "there is a positive relationship between stakes of stakeholders and economic performance of the business (H2a)", "there is a positive relationship between stakes of family members and economic performance of the business $(\mathrm{H} 2 \mathrm{~b})$ "and "there is a positive relationship between stakes of managers and economic performance of the business(H2c)". Summarizing these studies showing similarities and differences about these results $(\mathrm{H} 1, \mathrm{H} 2$ and sub-hypothesis) is possible in literature. 
According to Mitchell et. al. (1997) with Easley and Lenox (2006), satisfaction stakeholders' stakes and saliencies within the business, the power that stakeholder have, depends on the number of legitimacy and urgency attributes. They have low if they have one, medium if they have two, high urgency if they have three. According to Jones et. al. (2007), if a stakeholder only has power attributes, he/she has medium degree importance, if both power and urgency is high, and he/she has high degree importance. Yet, legitimacy does not have same degree of contribution. After all, total number of criteria that a stakeholder has, would change benefit and salience satisfaction rate of the stakeholder (Agle et. al, 1999). However, stakeholders did not consist of one single whole. In terms of power, legitimacy and urgency, they consist of more than single sub-group and each sub-group has specific stakes and saliencies (Ryan and Schneider, 2003). In the research, main stakeholder groups, which stakeholders, family members and managers compose, was focused on. In this context, when the result was examined in terms of stakeholders, in the study of Ring (2011), which had active role on creation of conceptual frame of the study, it was stated that in case of significance level of salience sand stakes of stakeholders being high, economic performance of the business would increase. Besides Davis and Taguiri (1989) with Mcgivern (1989) remarked that for Family businesses to be successful, they need to satisfy the stakes and saliencies of stockholders. Cragg and Greenbaum (2002) stated that businesses give more importance to stakes and saliencies of especially stakeholders of stakeholder groups to reach their goals; moreover, managers sometimes show unethical behaviors to fulfill personal goals of the stakeholders.

When it is evaluated in terms of family members, according to Ring (2011), in case the stakes and saliencies of family members are high, performance of the business would increase. Likewise, Tower et. al. (2007), Zachary (2011), Lee and Marshall (2013) and Basco (2014) also stated that there is a strong connection between stakes and saliencies of family members and economic performance of the family businesses and remarked that harmonization of saliencies and goals of the business would have positive effect on performance of the business. According to Cisneros et. al. (2012), as economic goals of the business is executed, ignoring stakes and saliencies of family system might cause conflicts in the business. However, focusing only on fulfilling the stakes and saliencies of family members might have negative effect on workers. Sindhuja (2009) stated that in consequence of stakes and saliencies of family members within Family businesses are at the forefront, they could not create values like normal businesses. Similarly, Ayranc1 (2004) emphasized that there is a weak relationship between family system and financial performance of the Family businesses. Birthistle and Fleming (2007) emphasized that Family businesses are employment source for family members and especially that they are under high effect of nepotism.

When evaluated in terms of managers, Ring (2011) stated that manager's high saliencies and stakes does not affect performance of the business. In addition to these, in satisfaction of stakes and saliencies of stakeholders, relationship with stakeholders plays a critical role (Steurer et. al., 2005). According to Rowley (1997), the more the intensity of communication between stakeholder and business increases, the more pressure stakeholders give to business and the more centralization increases, the more business's resistance against stakeholder's pressure increases. Therefore, business and stakeholder choose the way of cooperation. If the communication between stakeholder and the business is low but centralization is high, the business adopts the role of commandership and controls the stakes of stakeholders. However, if communication is high and centralization is low, business fulfills the stakes of stakeholder. If both communication and centralization is low, business tries to evade the pressure of the stakeholder. 
Consequently, satisfying stakes and saliencies of all stakeholder groups within Family businesses would direct all the motivation of stakeholder groups to the goals of the business. Therefore, this situation would have a positive effect on business performance.

\section{Conclusion}

When added-value they provide and economic weights they carry is considered, it is seen that weights of Family businesses both in our country and in world economies constitute vital point of nation economies. Thus, providing continuity of these businesses' activities growingly offers strategically importance for all nation economies. Especially, in an environment where economic inconsistency is experienced in many nations and many businesses could not provide their sustainability because of the risks, disappearance of Family businesses owing to stakeholder benefit conflict within the business gives huge damages to our nation and other nation economies. A family businesses management not providing stakeholder balance and causing conflicts will lose stakeholders and workers over time because of conflicts and also sustainability of the business will be in danger. In this context, as research findings support, to maintain their sustainability, strategies, which would emerge the strong sides of Family businesses to forefront, should be chosen, independent board of directors should be formed, Succession Plan should be prepared, role complexity should be forbidden and especially stakes and saliencies of all stakeholders should be determined. Execution of these applications involves a hard and long process. In application of this process successfully, professional support of experts plays a critical role. In inclusion of this support, independent board of directors plays an active role. Because professional managers through independent board of directors plays an active role in business management objectively. Thus, objective and fair management would be provided in strategic decisions and distribution of resources for the business. Consequently, as Schwartz and Barnes (1991) stated, existence of independent professional managers in management is necessary for Family businesses wanting to be successful. Because this manager can obtain professional objectivity to all incidents by minding business stakes.

Surely, while executing economic purposes of the business, personal stakes of these talented members within the family system should be satisfied. Otherwise, they might cause conflict within the business. However as Cisneros et. al. (2012) stated focusing all the attention on fulfilling the stakes and saliencies of family members might have negative effect on other workers. Generally, in Family businesses, considering the stakes and saliencies of certain stakeholder groups to achieve corporate success is a wrong approach. Present wealth should be distributed with an equal approach to all stakeholder groups who are thought to have contribution on family businesses. This plays a critical role in increasing economic performance and providing sustainability of the business. Otherwise, stakeholder system can be abandoned, and, in this case, this might damage economic performance and sustainability of the business (Clarkson, 1995).

Besides, in the study, though it was not anticipated, a mutual mathematical relationship emerged among stakes and saliencies belonging to stakeholders as the result of DFA analysis. It is seen that these two concepts are always dealt together in the literature. If stakes and priorities, which are in mutual relation with stakeholders, are integrated with goals of the business, increasing the economic performance and providing the sustainability would be much easier (Heugens et. al., 2002; Easley and Lenox, 2006). These research findings also support this idea. 


\section{References}

Agle, B.R., Mitchell, R.K. \& Sonnenfeld, J.A. (1999). Who matters to CEOS? an investigation of stakeholder attributes and salience, corporate performance, and CEO values. Academy Of Management Journal, 42,(5), 507-525.

Ayranc1, E. (2014). A study on the influence of family on family business and its relationship to satisfaction with financial performance. Ekonomie A Management, 2, 87-105.

Basco, R. (2014). Exploring the influence of the family upon firm performance: does strategic behavior matter? International Small Business Journal, December 32, 967-995.

Birdthistle, N. \& Fleming, P. (2007). Under the microscope: a profile of the family business in Ireland. Irish Journal Of Management, 28(2), 135-165.

Chevalier, J. (2001). Stakeholder analysis and natural resource management. e.t.01.06.2014 http://www1.worldbank.org/publicsector/politicaleconomy/November3Seminar/Stak ehlder\%20Readings/SA-Chevalier.pdf

Chua, J.H., Chrisman, J.J. \& Sharma, P. (1999). Defining the family business by behavior. Entrepreneurship: Theory and Practice, 23,(4), 19-37.

Cisneros, L., Genin, E. \& Peerally, J. (2012). Family, business and power: illustrating three extreme cases" Journal of Family Business Management, 2,(1), 40-56.

Clarkson, M.B.E. (1995). A stakeholder framework for analyzing and evaluating corporate social performance. Academy Of Management Review, 20,(1), 92-117.

Cragg, W. \& Greenbaum, A. (2002). Reasoning about responsibilities: mining company managers on what stakeholders are owned. Journal of Business Ethics, 39, 319-335.

Davis, J.A. \& Tagiuri, R. (1989). The influence of life-stage on father-son work relationships in family companies. Family Business Review, 2(1), 47-74.

Donaldson, T. \& Preston, L.E. (1995). The stakeholder theory of the corporation: concepts, evidence, and implications. Academy Of Management Review, 20, 1, 65-91.

Easley, C. \& Lenox, M.J. (2006). Firm responses to secondary stakeholder action. Strategic Management Journal, 27, 765-781.

Elias, A.A. \& Cavana, R.Y. (2000). Stakeholder analysis for systems thinking and modeling. 35th Annual Conference Of The Operational Research Society Of New Zealand, 1-18.

Erdirençelebi, M. (2013). Aile işletmelerinde kurumsallaşmanın gerçekleşmesi ile sürdürülebilirliğin sağlanmasında kuşaklar arası farklılıklar. Yayınlanmamış Doktora Tezi, Selçuk Üniversitesi Sosyal Bilimler Enstitüsü, Konya.

Freeman, R. E. (1984). Strategic management: a stakeholder approach, Pitman, Boston.

Freeman, E.R. \& Mcvea, J.F. (2001). A stakeholder approach to strategic management. SSRN Electronic Journal, 1(2), 1-33.

Heugens, P.P., Van Den Bosch, F.A.J. \& Van Riel, C.B.M. (2002). Stakeholder integration. Business\&Society, 41,(1), 36-60.

Hooper, D., Couglan, J. \& Mullen, M.R. (2008). Structural equation modeling: guidelines for determining model fit. Electronic journal of business research methods, 6(1), 53-60.

Jones, T., Felps, W. \& Bigley, G.A. (2007). Ethical theory and stakeholder related decisions: the role of stakeholder culture. Academy Of Management Review, 32,(1), 137-155.

Karpuzoğlu, E. (2000). Büyüyen ve gelişen aile işletmelerinde kurumsallaşma, Hayat Yayınları, İstanbul.

Kurt, B. (2009). Örgüt kültürünün aile şirketlerinin kurumsallaşmasında rolü. Yayınlanmamış Yüksek Lisans Tezi, Dokuz Eylül Üniversitesi Sosyal Bilimler Enstitüsü, İzmir.

Lansberg, I. \& Astrachan, J.H. (1994). Influence of family relationships on succession planning and training: the importance of mediating factors. Family Business Review, 2, 345362.

Lee, Y.G. \& Marshall, M.I. (2013). Goal orientation and performance of family business. $J$ Fam Econ Iss, 34, 265-274. 
Mainardes, E.W., Alves, H.\& Raposo M. (2011). Stakeholder theory: issues to resolve. Management Decision, 49, 2, 226-252.

Mcgivern, C. (1989). The dynamics of management succession: a model of chief executive succession in the small family firm. Family Business Review, 2(4), 401-411.

Mitchell, R.K., Agle, B.R.\& Wood, D.J. (1997). Toward a theory of stakeholder identification and salience: defining the principle of who and what really counts. Academy of Management Review, 22, 4, 853-886.

Mustakallio, M.A. (2002). Contractual and relational governance in family firms effects on strategic decision making quality and firm performance. Unpublished PhD Thesis, Helsinki University Of Technology Institute Of Strategy and International Business, Finland.

Neville B.A., Bell P.J. \& Mengüç, B. (2005). Corporate reputation, stakeholders and the social performance- financial performance relationship. European Journal Of Marketing, 39 (9/10), 1184-1198.

Polonsky, M.J. (1996). Stakeholder management and the stakeholder matrix: potential strategic marketing tools. Journal of Market-Focused Management, 1,(3),209-229.

Post, J.E., Preston, L.E. \& Sachs P. (2002). Managing the extended enterprise: the new stakeholder view. California Management Review, 45,(1), 6-28.

Preston, L.E. \& Sapienza, H.J. (1990). Stakeholder management and corporate performance. The Journal of Behavioral Economics, 19,(4),361-375.

Ring, J.K. (2011). Stakeholder salience in family firm. Unpublished PhD Thesis, Mississippi State University, ABD.

Rowley, T.J. (1997). Moving beyond dyadic ties: a network theory of stakeholder influences. Academy Of Management Review, 22,(4), 887-910.

Ryan, L.V. \& Schneider, M. (2003). Instutional investor power and heterogeneity: implications for agency and stakeholder theories. Business \&Society, 42(4), 398-429.

Schwartz, M.A. \& Barnes, L.B. (1991). Outside boards and family businesses: another look. Family Business Review, 4(3), 269-285.

Scott, P.G. \& Lane, V.R. (2000). A stakeholder approach to organizational identity. Academy of Management Review, January 1, 43-62.

Sindhuja, P.N. (2009). Performance and value creation: family managed business versus nonfamily managed business. IUP Journal of Business Strategy, 6,(3/4), 66-80.

Steurer, R., Langer, M.E., Konrad, A. \& Martinuzz, A. (2005). Corporations, stakeholder and sustainable development: a theoretical exploration of business-society relations. Journal Of Business Ethics, 61, 263-281.

Tower, B.C., Gudmunson, D., Schierstedt, S. \& Hartman E.A. (2007). Do family meetings really matter? Their relationship to planning and performance outcomes in small family business. Journal Of Small Business Strategy, Spring/Summer 18:(1), 85-93.

Zachary, R.K. (2011). The importance of family system in family business. Journal Of Family Business Management, 1,(1), 26-36. 